\title{
Zika virus is set to spread through Asia, WHO says
}

\section{Owen Dyer}

Montreal

Zika virus infection is "highly likely" to continue spreading through Asia, the World Health Organization predicted this week, as evidence grows that babies infected in the womb show a constellation of abnormalities, not just microcephaly.

A six month follow-up of 11 babies born to mothers diagnosed with the Zika virus in Brazil, published in JAMA Neurology, found a range of anomalies in addition to small head circumference. Amilcar Tanuri, of the Universidade Federal do Rio de Janeiro, Brazil, and coauthors have suggested naming the condition "congenital Zika syndrome."

Three of the 11 babies died within 48 hours of birth. The authors noted, "Combined findings from clinical, laboratory, imaging, and pathological examinations provided a more complete picture of the severe damage and abnormalities caused by ZIKV [Zika virus] infection than had been previously reported."

The findings included microcephaly, a reduction in cerebral volume, ventriculomegaly, cerebellar hypoplasia, lissencephaly with hydrocephalus, and fetal akinesia deformation sequence (arthrogryposis).

Zika virus, which is spread by the Aedes aegypti mosquito, was not known to cause birth defects before a large outbreak spread through northeastern states in Brazil in early 2015. The prospective study in Campina Grande, in the state of Paraiba, observed more than 150 women with symptoms of Zika infection and chose the 11 women whose fetuses were found to have brain lesions during fetal ultrasound imaging.

In a JAMA opinion piece Thomas Frieden and coauthors from the US Centers for Disease Control and Prevention said, "For the public health community, Zika represents an unprecedented emergency. Never before, to our knowledge, has a mosquito-borne virus been associated with human birth defects or been capable of sexual transmission." 2 The virus can remain viable in semen for months and may possibly be passed through tears or sweat.

A year on from the spike in births of babies with microcephaly in Brazil, doctors have seen many of the babies developing swallowing difficulties, epileptic seizures, and sight and hearing problems. Vanessa van der Linden, a paediatric neurologist in Recife, told Associated Press this month, "We are seeing a lot of seizures. And now they are having many problems eating, so a lot of these children start using feeding tubes."

Of around 70 countries where Zika infections have been found, 19 are in the Asia Pacific area, the second most affected region after the Americas. Singapore has reported hundreds of cases of infection, and two Zika related microcephaly cases have been reported in Thailand.

In a report released on 11 October WHO said that it was "highly likely that locally acquired or imported cases of Zika virus infection will occur in additional countries and areas within the region," which includes China, Japan, Australia, most South East Asian nations, and the Pacific islands. ${ }^{4}$

Melo AS, Aguiar RS, Amorim MM, et al. Congenital Zika virus infection: beyond neonatal microcephaly. JAMA Neurol 2016. doi:10.1001/jamaneurol.2016.3720. pmid:27695855. Frieden TR, Schuchat A, Petersen LR. Zika virus 6 months later. JAMA 2016;316:1443-4. doi:10.1001/jama.2016.11941. pmid:27532277.

3 Swaminathan S, Schlaberg R, Lewis J, Hanson KE, Couturier MR. Fatal Zika virus infection with secondary nonsexual transmission. N Engl J Med 2016. doi:10.1056/ NEJMc1610613. pmid:27681699.

4 World Health Organization. Zika risk assessment in the Western Pacific Region (as of 11 October 2016). 2016. www.wpro.who.int/outbreaks_emergencies/zika/WPR_Zika_ RiskAssessment/en/.

Published by the BMJ Publishing Group Limited. For permission to use (where not already granted under a licence) please go to http://group.bmj.com/group/rights-licensing/ permissions 